\title{
AKSElerASI:
}

\section{PENGGUNAAN TEKNOLOGI INTERNET DALAM PROSES PEMBELAJARAN MATEMATIKA SEKOLAH DASAR DI MASA PANDEMI COVID-19}

\author{
Wahyu Aditya Rahmawati \\ IAIN Kudus, Jl. Gondangmanis No. 51, Ngembal Rejo, Bae, Kudus, Jawa Tengah Indonesia \\ e-mail:wahyuaditya3011@gmail.com
}

DOI: 10.35719/akselerasi.v2i2.90

\begin{abstract}
Elementary school students have entered certain operational stages, so they need a media that can master various existing concepts. Mathematics appears to be an abstract subject. Learning mathematics requires specific objects and explanations from the teacher. The existence of this corona virus outbreak allows people to learn online, including learning mathematics. The purpose of this study is to describe the process of learning mathematics using internet technology during the corona virus pandemic and to describe the impact of online or online learning during the corona virus pandemic. This research method is a qualitative method using interviews and literature research. The result of this research is that the mathematics learning process is carried out online or called online in various schools, and some still require parents to bring their child's assignments to school. although it has maximized the use of the internet in the learning process. In this pandemic, both teachers, students and parents feel various influences during online learning, some of which are positive or negative.
\end{abstract}

Keywords : Covid-19 Pandemic, Internet Technology, Math Learning

\section{ABSTRAK}

Peserta didik sekolah dasar sudah memasuki tahapan operasi tertentu, sehingga membutuhkan suatu media yang dapat menguasai berbagai konsep yang ada. Matematika tampaknya menjadi salah satu mata pelajaran yang abstrak. Pembelajaran matematika membutuhkan objek dan penjelasan khusus dari guru. Adanya wabah virus corona ini memungkinkan masyarakat belajar secara online, tak terkecuali belajar mata pelajaran matematika. Tujuan penelitian ini adalah mendeskripsikan proses pembelajaran matematika dengan pemanfaatan teknologi internet pada masa pandemi virus corona dan mendeskripsikan dampak adanya pembelajaran online atau daring pada saat pandemi virus corona ini. Metode penelitian ini adalah metode kualitatif dengan menggunakan wawancara dan penelitian kepustakaan. Hasil dari penelitian ini adalah proses pembelajaran matematika dilakukan secara online atau disebut daring di berbagai sekolah, dan beberapa masih mewajibkan orang tua untuk membawa tugas anaknya ke sekolah. meskipun telah memaksimalkan penggunaan internet dalam proses pembelajaran. Dalam pandemi ini, baik itu guru, siswa, dan orang tua tentu merasakan berbagai pengaruh selama pembelajaran online, beberapa di antaranya positif atau negatif. 
Kata Kunci : Pandemi covid-19, Teknologi internet, Pembelajaran Matematika

\section{PENDAHULUAN}

Pembelajaran matematika merupakan salah satu isi dari pembelajaran bertema sekolah dasar. Pembelajaran matematika di sekolah dasar tidak hanya berfokus pada penguasaan materi matematika, tetapi juga materi matematika diposisikan sebagai alat dan sarana bagi peserta didik untuk memperoleh kemampuan. Pada dasarnya pembelajaran matematika memiliki ciri-ciri abstrak, konsep dan prinsipnya berjenjang. Hal ini membuat banyak peserta didik kesulitan dalam mempelajari matematika. Penguasaan materi peserta didik menunjukkan keberhasilan pembelajaran matematika sekolah dasar.

Salah satu faktor keberhasilan dalam proses pembelajaran adalah memungkinkan peserta didik menguasai materi matematika dengan baik, yaitu kemampuan guru dalam merencanakan dan melaksanakan pembelajaran. Pembelajaran matematika peserta didik sekolah dasar kelas satu, dua, dan tiga sudah termasuk dalam tema tema yang dipelajari. Namun untuk kelas atas yaitu kelas IV, V, dan VI materi matematika dipisahkan dari buku materi tematik terpadu. Pemisahan materi matematika dalam buku tematik terpadu karena jika digabungkan, materi matematika yang diperoleh peserta didik dianggap dangkal, dan peserta didik tidak memiliki pemahaman konsep matematika yang mendalam.

Oleh karena itu, peserta didik kelas IV, V, dan VI menggunakan buku matematika tersendiri. Semenjak Corona virus Diseases 2019 (COVID-19) mulai masuk ke Indonesia pada awal Maret 2020, untuk proses pembelajaran yang sebelumnya dilakukan tatap muka dengan guru dan peserta didik lainnya kini semua telah diubah. Penyakit Corona virus Diseases 2019 (COVID19) merupakan jenis penyakit baru yang tidak pernah ditemukan sebelumnya dan virus ini menyerang manusia. Keberadaan virus Corona virus Diseases 2019 (COVID-19) berdampak pada semua aspek kehidupan masyarakat. Mulai dari bidang sosial, ekonomi, pariwisata, bahkan pendidikan pun sangat terpengaruh oleh virus ini.

Banyak sekolah-sekolah di berbagai negara / wilayah telah menutup sekolah-sekolah untuk meminimalkan penyebaran virus Corona virus Diseases 2019 (COVID-19). Melihat adanya situasi tersebut, Menteri Pendidikan dan Kebudayaan Republik Indonesia Nadiem Anwar Makarim menerbitkan Surat Edaran Nomor 4 Tahun 2020 pada tanggal 24 Maret 2020 yang berisi tentang Corona virus Diseases 2019 (COVID- 19) Menerapkan kebijakan pada pendidikan selama keadaan darurat.

Dalam surat edaran tersebut disebutkan bahwa proses pembelajaran dilakukan secara online atau jarak jauh di rumah, tanpa perlu bertemu dengan peserta didik secara langsung, sehingga memberikan peserta didik pengalaman belajar yang lebih bermakna. Dengan tujuan yang tidak lain adalah untuk mencegah penyebaran virus Corona virus Diseases 2019 (COVID-19) yang 
lebih cepat tersebarnya. Penyebaran virus Corona virus Diseases 2019 (COVID-19) yaitu dapat melalui muntah (fomites) maupun melalui tetesan air liur (water droplets) dalam kontak dekat tanpa pelindung apapun.

Dalam masa pandemi Corona virus Diseases 2019 (COVID-19) saat ini, pembelajaran online adalah pembelajaran yang memanfaatkan adanya teknologi internet yang dapat dijadikan sebagai alat atau media pembelajaran. Namun, perubahan yang terjadi secara mendadak dalam proses pembelajaran akibat virus Corona virus Diseases 2019 (COVID-19) ini kerap membuat kaget para guru (pendidik), peserta didik, dan orang tua. Perubahan ini menuntut pendidik merespons dengan sikap dan tindakan, serta mau mempelajari hal-hal yang baru.

Penggunaan teknologi internet harus menjadi rujukan bagi seorang pendidik untuk menghasilkan proses pembelajaran yang memberikan ruang bagi peserta didik untuk mengeksplorasi dan dapat menjadikan peserta didik berkolaborasi antar peserta didik dengan peserta didik lainnya atau peserta didik dengan guru. Dalam proses pembelajaran online yang dilakukan oleh guru dan peserta didik, penyusunan bahan dan penggunaan alat peraga atau media pembelajaran harus disesuaikan dengan tingkat perkembangan intelektual para peserta didik.

Hal tersebut dilakukan untuk memudahkan peserta didik dalam memahami materi yang diajarkan. Menurut Piaget, tingkat perkembangan intelektual peserta didik pada sekolah dasar berkisar usia rata-rata 6-11 tahun. Dimana usia tersebut berada pada tahap concurrent operation (Bujuri, 2018). Oleh karena itu, ketika menanamkan konsep dasar matematika kepada peserta didik tingkat sekolah dasar, sebaiknya dimulai dengan pengenalan materi tertentu, kemudian diawali dengan pengenalan materi semi konkrit, kemudian gunakan simbol-simbol matematika untuk mengenalkan materi secara abstrak.

Selain itu, Brunner juga mengungkapkan bahwa peserta didik ditingkat sekolah dasar akan berkembang melalui 3 tahap perkembangan mental yaitu enaktif, kornik, dan simbolik. Belajar mengenai konsep serta struktur materi matematika dimulai dengan cara pengenalan masalah yang bersifat kontekstual. Dengan mengajukan masalah yang bersifat kontekstual, peserta didik dibimbing secara bertahap untuk menguasai konsep yang ada dalam matematika. Untuk meningkatkan keefektifan dan memaksimalkan pembelajaran matematika yang dilakukan secara online, maka diperlukan teknologi internet dan alat peraga atau media, seperti penggunaan internet sebagai penunjang pelaksanaannya dan media sebagai alat bantu proses kegiatan pembelajaran agar mencapai tujuan pembelajaran yang telah ditentukan.

Penggunaan teknologi internet untuk tujuan pendidikan semakin meningkat, terutama di negara maju. Fakta ini ditunjukkan bahwa media semacam ini memang dapat digunakan dalam proses pembelajaran sehingga lebih efektif. ${ }^{1}$ Melalui pembelajaran online atau jarak jauh yang ditetapkan, peserta didik dapat menggunakan beberapa aplikasi untuk berinteraksi dengan guru

\footnotetext{
${ }^{1}$ Haryanto, Tekhnologi Pendidikan, (Yogjakarta: UNY Press, 2015), hal.3.
} 
dalam proses pelaksanaan pembelajaran. seperti google classroom, video fusion, zoom cloud meeting, google meet, whatsapp, atau lainnya. Pembelajaran dengan aplikasi ini merupakan inovasi dalam industri pendidikan dan tantangan yang dihadapi pendidik dalam mempersiapkan materi pengajaran dalam bentuk online atau jarak jauh.

Penggunaan internet sebagai media pembelajaran online tidak akan berdampak baik bagi semua peserta didik. Hal ini dikarenakan banyak faktor yang mempengaruhi keberhasilan peserta didik dalam melaksanakan pembelajaran online atau jarak jauh. Faktor yang mempengaruhi keberhasilan peserta didik tersebut antara lain adalah lingkungan dan karakteristiknya peserta didik itu sendiri. ${ }^{2}$ Faktor lingkungan yang tersirat tersebut antara lain adalah peran dan kesiapan orang tua dalam membimbing anaknya ketika sedang melakukan belajar secara online atau jarak jauh, dan faktor lain yakni ratanya penyebaran akses Internet di berbagai wilayah Indonesia.

Jika akses internet berjalan dengan lancar, maka pembelajaran online atau jarak jauh yang dilakukan juga akan berjalan dengan lancar. Adapun, ciri-ciri peserta didik yang mempengaruhi keberhasilan dalam pembelajaran online atau jarak jauh adalah peserta didik yang memiliki rasa antusiasisme dan semangat yang tinggi dalam mengikuti proses pembelajaran. Jika peserta didik memiliki rasa antusiasme yang tinggi untuk mengikuti pembelajaran online, maka hasilnya akan bisa maksimal. Begitu pula jika rasa antusiasme peserta didik rendah, maka hasilnya tidak akan maksimal. Dalam proses pembelajaran online atau jarak jauh tentunya mengalami kendala-kendala yang dialami oleh pendidik. Dan itu menjadi tantangan tersendiri bagi pendidik untuk mentransformasikan pendidikan ke jenjang yang lebih tinggi. Apalagi dalam pembelajaran mata pelajaran matematika, kebanyakan peserta didik akan mengalami kesulitan belajar jika tidak berhadapan langsung dengan guru.

Oleh karena itu, tujuan dari penelitian ini adalah untuk mendeskripsikan tentang penggunaan teknologi internet dalam proses pembelajaran matematika selama terjadinya virus Corona virus Diseases 2019 (COVID-19) dan memperoleh informasi mengenai dampak adanya virus Corona virus Diseases 2019 (COVID-19) terhadap pelaksanaan pembelajaran matematika yang dilakukan secara online atau jarak jauh pada tingkatan sekolah dasar.

\section{METODE}

Penelitian ini menggunakan metode kualitatif. Penelitian ini menggunakan studi kasus eksploratif untuk mendapatkan informasi tentang proses pembelajaran matematika dengan penggunaan teknologi internet dan apa saja kendala yang dihadapi selama pandemi COVID-19 dalam proses pembelajaran secara online ini. Metode pengumpulan data menggunakan wawancara

2 Wiryanto, Proses Pembelajaran Matematika Di Sekolah Dasar Di Tengah Pandemi Covid-19, Jurnal Review Pendidikan Dasar: Jurnal Kajian Pendidikan dan Hasil Penelitian, Vol. 6, No. 2 2020. Hal.3. 
semi terstruktur sebagai data utama. Sedangkan data pembantu dengan bentuk penelitian kepustakaan.

Wawancara dilakukan melalui jaringan telepon dengan menelepon dengan rata-rata waktu 12 menit. Wawancara yang dilakukan melalui telepon dirancang untuk mendukung program social distancing, yang digunakan untuk mencegah penularan COVID-19. Dalam penelitian ini mewawancarai 6 narasumber, termasuk 2 guru, 2 orang tua atau wali dari peserta didik, dan 2 peserta didik yang bersekolah berbeda-beda di wilayah Mlonggo Kabupaten Jepara. Untuk menjaga kerahasiaan, data dari narasumber disingkat R1-R6. Berikut gambaran narasumber dalam penelitian ini :

Tabel.1 Profil Narasumber

\begin{tabular}{|c|c|c|}
\hline Inisial & Jenis kelamin & Peran \\
\hline R1 & Perempuan & Guru kelas IV \\
\hline R2 & Laki-laki & Guru kelas V \\
\hline R3 & Perempuan & Orangtua V \\
\hline R4 & Perempuan & Orangtua IV \\
\hline R5 & Perempuan & Peserta didik V \\
\hline R6 & Laki-laki & Peserta didik IV \\
\hline
\end{tabular}

\section{HASIL DAN PEMBAHASAN}

\section{Penggunaan Teknologi Internet}

1. Pengertian Internet

Internet adalah singkatan dari interconnected network karena fungsinya untuk menghubungkan jaringan komputer di seluruh dunia. ${ }^{3}$ Melalui fungsi ini, Internet berkembang dan membawa banyak manfaat bagi perkembangan dunia.

Menurut definisi, Internet adalah sistem jaringan yang menghubungkan berbagai komputer dari seluruh dunia untuk menghubungkan dan bertukar data serta bertukar informasi. Faktanya, komputer yang terhubung ke komputer lain membutuhkan bantuan program kecil yang disebut browser. Di dunia ini perkembangan aplikasi browser berkembang pesat seiring dengan perkembangan teknologi internet khususnya koneksi internet memiliki segala kelebihan dan kekurangannya. ${ }^{4}$

Karena kelebihan koneksi yang cepat, browser yang paling banyak digunakan adalah Mozilla Firefox. Namun, ada banyak opsi browser lain yang juga dapat digunakan untuk menyambung ke Internet. Dalam perkembangannya, internet telah menjadi jaringan komputer

${ }^{3}$ Yuhelizar, 10 Jam Menguasai Internet Teknologi dan Aplikasinya, (Jakarta: PT Elex Media Komputindo, 2008), hal.1.

${ }^{4}$ Jubilee Enterprise, Panduan Memilih Koneksi Internet untuk Pemula, (Jakarta: PT Elex Media Komputindo, 2010), hal.2. 
terbesar di dunia. (Jaringan mengacu pada sekelompok komputer yang terhubung bersama sehingga mereka dapat berbagi informasi dan sumber daya). Sesuai dengan namanya, Internet bukanlah jaringan tunggal, melainkan jaringan jaringan. Internet mengandung banyak standar untuk mentransfer informasi dari satu jaringan ke jaringan lainnya, sehingga jaringan di seluruh dunia dapat berkomunikasi. ${ }^{5}$

Padahal, internet telah melahirkan istilah baru yaitu dunia maya. Dunia tempat kita hidup disebut dunia nyata. Internet ada di antara keduanya. Karena salah satu fungsi internet adalah berfungsi sebagai penghubung antara dunia nyata dengan dunia maya. Dunia maya adalah tempat para pengguna internet berkomunikasi. Jadikan, internet itu sebagai jaringan komunikasi global. Jutaan orang di seluruh dunia menggunakan Internet untuk berbagai aktivitas, dari individu, organisasi hingga tujuan perusahaan. Banyak orang Indonesia di berbagai daerah juga menggunakan Internet. Tidak hanya di perusahaan, penggunaan internet juga sudah masuk ke sekolah sebagai sarana penting dalam kegiatan belajar. Internet bahkan lebih mudah digunakan di rumah. ${ }^{6}$

Karena banyaknya manfaat yang bisa didapat dengan menggunakan internet, maka internet telah menyebar ke seluruh dunia. Sebagai sumber informasi yang sangat besar, Internet tidak dapat ditangani oleh satu orang, satu organisasi, atau satu negara saja. Faktanya, tidak ada yang bisa memahami segala sesuatu di Internet. ${ }^{7}$ Dari berbagai informasi di atas tentang Internet, dapat disimpulkan bahwa Internet adalah jaringan komunikasi global dan sumber informasi, yang memungkinkan penggunanya untuk terhubung satu sama lain melalui program kecil yang disebut browser.

\section{Sejarah Internet}

Pada awal 1960-an, ahli komputer Amerika mencoba mengembangkan jaringan komputer. Tujuan dari penelitian ini adalah untuk menghubungkan secara langsung beberapa komputer dan penggunaannya. Pada tahun 1965, pemerintah AS mulai menyadari bahwa penggunaan komputer akan berdampak luas pada bidang penelitian dan pengembangan khususnya bidang militer. Pada tahun 1967, pendiri Internet Lawrence G. Roberts (Lawrence G. Roberts) merilis rancangan model perencanaan dan pengembangan ARPANet. ${ }^{8}$

Pada tahun 1969, ARPA (Advanced Research Projects Agency) di bawah Departemen Pertahanan AS meluncurkan proyek ARPANet, yang menciptakan jalur komunikasi yang tidak

\footnotetext{
${ }^{5}$ Clay Shirky, Internet Lewat E-Mail, (Jakarta: PT Elex Media Komputindo, 1995), hal.2.

${ }^{6}$ Annisa Rahmania, dkk., Internet Sehat, (Depok: Penebar Plus), hal.4. 1996), hal.8

${ }^{7}$ Lani Sidharta, Internet: Informasi Bebas Hambatan 2, (Jakarta: PT Elex Media Komputindo,

${ }^{8}$ Zaenal A. Rozi, Computer Started Guide; Mari Mengenal Internet, (Yogyakarta: Penerbit ANDI, 2008), hal.5
} 
dapat dihancurkan untuk mempromosikan kerja sama antar lembaga penelitian di seluruh negeri, termasuk industri senjata. ${ }^{9}$

RPANet membuat jaringan komputer terdistribusi untuk menghindari konsentrasi informasi, karena dianggap rawan kehancuran dalam perang. Pada awal 1980-an ARPANet dibagi menjadi dua jaringan, yaitu ARPANet dan Milnet (jaringan militer). Namun keduanya saling terkait, sehingga komunikasi antar jaringan tetap dapat dilakukan. ${ }^{10}$ Sejak itu, Internet berkembang pesat, mencakup hampir semua bidang kehidupan. Di Indonesia, Internet dikenal luas sekitar tahun 1995. ${ }^{11}$

Hingga saat ini, Internet telah berkembang dan tidak pernah mengalami penurunan. Jumlah komputer yang terhubung semakin meningkat, yang merupakan permintaan utama berbagai organisasi formal dan informal dan bahkan individu. Usia pengguna tidak dibatasi, dari anak-anak hingga orang tua yang aktif menggunakan Internet dalam kehidupan sehari-hari. Tidak dapat dipungkiri bahwa fungsi Internet sangat lengkap dalam segala aspek kehidupan. Hingga saat ini, masyarakat modern hidup tanpa lepas dari internet setiap hari.

\section{Pembelajaran Daring}

Perkembangan teknologi informasi berdampak besar terhadap perubahan di segala bidang. Salah satunya adalah perubahan bidang pendidikan. Teknologi dapat digunakan dalam kegiatan pengajaran, dapat dikatakan sebagai transformasi dari tradisional menjadi modern. Gheytasi, Azizifar dan Gowhary menyebutkan bahwa beberapa penelitian menunjukkan bahwa dengan adanya teknologi memberikan banyak pengaruh positif terhadap pembelajaran. Internet telah dipadukan menjadi sebuah alat yang digunakan untuk melengkapi aktivitas pembelajaran. ${ }^{12}$

COVID-19 berdampak besar pada seluruh sektor di dunia. Dampak yang terjadi akibat adanya COVID-19 ini seperti pada bidang ekonomi, pariwisata, sosial, dan tidak terkecuali pendidikan. Pada sektor pendidikan, banyak yang menghentikan kegiatan belajar mengajarnya dan memberhentikan program pertukaran pelajar untuk meminimalisir penyebaran COVID-19.

Penutupan sekolah adalah salah satu respon positif pemerintah untuk melindungi peserta didik dari kemungkinan tertular COVID-19, karena lingkungan sekolah merupakan tempat ratusan peserta didik bertemu dan ini menjadikan sekolah menjadi tempat yang berbahaya dimana penyakit dapat menyebar dengan cepat (Sintema, 2020).

Pemerintah Indonesia mengeluarkan surat pemberitahuan pada tanggal 19 Maret 2020, bahwa orang-orang menunda semua aktivitas-aktivitas luar ruangan di berbagai bidang terutama di

\footnotetext{
${ }^{9}$ Mathias Nolden, World Wide Web di Internet, (Jakarta: PT Elex Media Komputindo, 1996), hal.4

${ }^{10}$ Iskandar, Panduan Lengkap Internet, (Yogyakarta: Penerbit ANDI, 2009), hal.2.

${ }^{11}$ Erhans Anggawirya, Internet, (Cirebon:PT Ercontara Rajawali, ), hal.7.

12 Oktafia Ika Hndayani, Pembelajaran Daring Sebagai Upaya Study From Home (SFH) Selama
} Pndemi Covid-19, Jurnal Pendidikan Administrasi Perkantoran (JPAP), Vol. 8, No. 3, 2020. Hal. 498. 
alam bebas karena termasuk edukasi untuk mencegah penyebaran COVID-19. Surat dari Menteri Pendidikan dan Kebudayaan Nomor 4 Tahun 2020 memberitahukan tentang implementasi pendidikan dalam keadaan darurat untuk penyebaran COVID-19 dirilis pada 24 Maret 2020. Bahwasannya menjelaskan agar bisa melakukan kegiatan proses mengajar melalui sistem online atau jarak jauh. Pembelajaran online atau jarak jauh bukanlah sistem pembelajaran yang dilakukan secara langsung tatap muka, tetapi menggunakan platform untuk membantu proses belajar mengajar, bahkan dalam jarak yang jauh. ${ }^{13}$ Pembelajaran online atau jarak jauh telah diterapkan secara global selama masa pandemi COVID-19. Pembelajaran tersebut dilakukan agar dunia pendidikan tetap berjalan dengan semestinya. Jarak fisik atau physical distancing diperlukan. Pembelajaran online atau jarak jauh dilakukan agar peserta didik mempunyai pengalaman belajar baru yang bermakna.

Ada beberapa aplikasi yang juga dapat membantu kegiatan mengajar, seperti whatsapp, zoom, web blog, edmodo, dll. Pemerintah juga berperan dalam mengatasi ketimpangan dalam kegiatan belajar selama 19 pandemi. Dengan meluncurkan situs resmi dari Kementerian Pendidikan dan Kebudayaan Indonesia, peserta didik dapat mengakses 12 platform atau aplikasi untuk belajar di rumah, yaitu: (1) Learning Center (2) Meja Kita (3) Icando (4) Indonesiax (5) Google Education Edition (6) Smart Class (7) Microsoft Office 365 (8) Quipper School (9) Ruang Guru (10) Sekolahmu (11) Zenius (12) Cisco webex. ${ }^{14}$

Pembelajaran online atau jarak jauh dapat terlaksana dengan baik apabila didukung oleh komponen-komponen pembentuknya. (Winarno \& Setiawan , 2013) Beberapa komponen tersebut yaitu: Infrastruktur e-learning, dapat berupa perangkat komputer atau perangkat yang dimiliki, jaringan internet, dan perangkat telekonferensi (2) Sistem dan aplikasi e-learning, termasuk sistem perangkat lunak yang digunakan, seperti pengelolaan kelas, materi, dan diskusi forum dan sistem evaluasi (3) Isi e-learning, termasuk buku teks dalam format multimedia atau teks. ${ }^{15}$

Salah satu tantangan pembelajaran online atau jarak jauh adalah keahlian pendidik dan pendidik dalam penggunaan teknologi. Dabbagh (dalam Hasanah et al., 2020: 3) mengemukakan bahwa karakteristik peserta didik dalam kegiatan pembelajaran online atau jarak jauh adalah:

1. Semangat belajar; semangat peserta didik yang kuat dan tinggi saat proses pembelajaran guna sebagai pembelajaran mandiri. Karena dalam pembelajaran online atau jarak jauh, peserta didik menentukan sendiri standar pemahaman lengkap materi pembelajaran yang diperolehnya.

${ }^{13}$ Wiryanto, Proses Pembelajaran Matematika di Sekolah Dasar di Tengah Pandemi Covid-19, Jurnal Kajian Pendidikan dan Hasil Penelitian, Vol. 6, No. 2, Mei 2019.

${ }^{14}$ Oktafia Ika Hndayani, Pembelajaran Daring Sebagai Upaya Study From Home (SFH) Selama Pndemi Covid-19, Jurnal Pendidikan Administrasi Perkantoran (JPAP), Vol. 8, No. 3, 2020. hal. 498.

${ }^{15}$ Dede rahmad dkk, Kemandirian Belajar Peserta Didik dalam Pembelajaran Daring Pada Masa Pandemi Covid-19, Jurnal Prespektif Ilmu Pendidikan, Vol. 34, No.2, Oktober 2020. hal. 149-150. 
2. Literacy terhadap teknologi; selain kemandirian terhadap kegiatan pembelajaran online atau jarak jauh, tingkat pemahaman peserta didik terhadap pemakaian teknologi internet juga sangat penting.

3. Kemampuan berkomunikasi interpersonal; selain semangat belajar dan literacy terhadap teknologi, peserta didik harus menguasai keterampilan komunikasi dan keterampilan interpersonal. Ini merupakan salah satu syarat untuk suksesnya pembelajaran online atau jarak jauh. Keterampilan interpersonal juga diperlukan untuk menjalin hubungan dan interaksi antar peserta didik lainnya. Sebagai makhluk sosial, meskipun pembelajaran online atau jarak jauh dilakukan secara mandiri, kita tetap perlu berinteraksi dengan orang lain. Oleh karena itu, keterampilan interpersonal dan keterampilan komunikasi harus tetap dilatihkan dalam kehidupan sosial.

4. Berkolaborasi; melalui pembelajaran online atau jarak jauh, peserta didik juga harus dapat memahami pembelajaran yang kolaboratif, serta dapat melatih peserta didik untuk berkolaborasi dengan lingkungan sekitar atau berbagai sistem yang mendukung pembelajaran online atau jarak jauh.

5. Keterampilan untuk belajar mandiri; Salah satu ciri pembelajaran online atau jarak jauh adalah kemampuan belajar mandiri oleh peserta didik. Karena ketika proses pembelajaran online, peserta didik mencari, menemukan sampai dengan menyimpulkan sendiri yang telah ia pelajari. ${ }^{16}$

\section{Pembelajaran Matematika di Sekolah Dasar}

1. Pengertian pembelajaran matematika

Matematika merupakan salah satu dari enam disiplin ilmu yaitu matematika, fisika, biologi, psikologi, ilmu sosial, dan linguistik. Berdasarkan sudut pandang konstruktivisme, hakikat matematika adalah bahwa anak yang belajar matematika akan menghadapi masalah tertentu dalam proses belajar dan berusaha memecahkan pengetahuan matematika. ${ }^{17}$

Ciri utama matematika adalah penalaran deduktif, yaitu kebenaran konsep atau pernyataan yang diperoleh sebagai hasil logis dari fakta sebelumnya. Namun, ketika mempelajari konsep, pemahaman biasanya dimulai secara induktif melalui pengalaman kejadian nyata. Proses deduksi induktif dapat digunakan untuk mempelajari konsep matematika. Dalam proses pembelajaran matematika di kelas sering dijumpai rumus atau atribut yang diperoleh dari penalaran deduktif atau induktif dapat digunakan, walaupun hal ini secara formal tidak disebut pembelajaran inferensial. ${ }^{18}$

${ }^{16}$ Oktafia Ika Hndayani, Pembelajaran Daring Sebagai Upaya Study From Home (SFH) Selama Pndemi Covid-19, Jurnal Pendidikan Administrasi Perkantoran (JPAP), Vol. 8, No. 3, 2020. hal. 498.

${ }^{17}$ Hamzah, Model Pembelajaran (Jakarta: PT. Bumi Aksara, 2007), hal. 126-132

${ }^{18}$ Depdiknas, Pembelajaran Matematika (Jakarta: Depdiknas, 2003), hal. 5-6. 
Matematika adalah studi tentang perhitungan, evaluasi, dan penggunaan penalaran sendiri atau kemampuan berpikir logis dan kemampuan untuk berpikiran jernih. Sedangkan pembelajaran merupakan suatu proses mengajar peserta didik dalam pembelajaran yang diselenggarakan oleh guru. Bagaimana belajar memperoleh dan memproses pengetahuan, keterampilan dan sikap ${ }^{19}$ Pembelajaran matematika merupakan suatu proses pemberian pengalaman belajar kepada peserta didik melalui serangkaian kegiatan yang direncanakan agar peserta didik dapat memperoleh kemampuan materi matematika yang dipelajari. ${ }^{20}$

2. Tujuan pembelajaran matematika

Tujuan belajar matematika adalah untuk melatih dan menumbuhkan cara berpikir yang sistematis, logis, kritis, kreatif dan konsisten, serta mengembangkan sikap yang langgeng dan percaya diri dalam memecahkan masalah. ${ }^{21}$

Tujuan mata pelajaran matematika yang tercantum dalam KTSP SD / MI adalah untuk membekali siswa dengan kemampuan sebagai berikut :

a. Memahami konsep matematika, menjelaskan hubungan antar konsep, dan menerapkan konsep atau logaritma secara luwes, akurat, efisien dan tepat.

b. Penalaran menggunakan pola dan atribut, melakukan operasi matematika saat menggeneralisasi, mengumpulkan bukti, atau menjelaskan ide dan pernyataan matematika.

c. Masalah yang akan dipecahkan meliputi kemampuan memahami, merancang model matematika, memecahkan model dan menginterpretasikan solusi yang diperoleh.

d. Mengkomunikasikan simbol, tabel, diagram atau media lain untuk memperjelas situasi atau masalah. ${ }^{22}$

3. Ciri-ciri pembelajaran matematika sekolah dasar

Suwangsih dan Tiurlina (2006) menyampaikan paparan ciri-ciri pembelajaran matematika diantaranya :

a. Pembelajaran matematika menggunakan pendekatan spiral

Pendekatan dalam pembelajaran matematika yang dimana memperkenalkan konsep baru dengan memperhatikan konsep yang dipelajari peserta didik sebelumnya.

b. Pembelajaran matematika bertahap

${ }^{19}$ Dimyati, dan Mujiono, Belajar dan Pembelajaran (Jakarta: Rineka Cipta, 2002), hal. 157.

${ }^{20}$ Muksetyo Gatoto, dkk.,Pembelajaran Matematika SD (Jakarta: Uneversitas terbuka, 2007), hal. 126.

${ }^{21}$ Prihandoko, Pemahaman dan Penyajian Konsep Matematika Secara Benar dan Menarik (Jakarta : Dediknas ,2006), hal. 21.

${ }^{22}$ Suwangsih dan Tiurlina, Pembelajaran Matematikan ( Bandung : UPI press , 2006) 
Pembelajaran matematika harus berjalan secara bertahap apalagi peserta didik sekolah dasar yang memang berada pada taraf berfikir secara operasional konkret, pembelajaran dimulai dari tahap konkret dengan menggunakan benda-benda nyata dalam praktik pembelajaran kemudia masuk tahap semi konkret dengan menggunakan media gambar dan yang terakhir tahap abstrak dengan menggunakan simbol-simbol.

c. Pembelajaran matematika menggunakan metode induktif

Dengan metode induktif, peserta didik akan lebih mudah mengumpulkan faktafakta terlebih dahulu setelah itu baru menarik generalisasi daripada memahami generalisasi baru mengumpulkan fakta-fakta (Karso, 2008)

d. Pembelajaran matematika menganut kebenaran konsistensi

Maksudnya disini tidak adanya pertentangan antara kebenaran satu dengan lainnya karena konsep matematika saling keterkaitan satu sama lainnya untuk mempermudah pemahaman pembelajaran matematika

e. Pembelajaran matematika hendaknya bermakna

Pembelajaran bermakna dapat tercipta dengan melalui penemuan, dimana peserta didik terlibat dalam pembentukan konsep dan pemecahan masalah. Konsep yang diajarkan sebaiknya yang bersifat relevan dengan pengetahuan awal yang dimiliki peserta didik sebelumnya agar peserta didik tidak mengalami hembatan dalam mengikuti pembelajaran. ${ }^{23}$

\section{Penggunaan teknologi internet dalam proses pembelajaran matematika di sekolah dasar pada masa pandemi COVID-19}

Pada masa pendemi COVID-19 yang terjadi saat ini, penggunaan teknologi internet sangatlah diperlukan. Karena pembelajaran yang pada mulanya dilakukan secara tatap muka (face to face) berubah menjadi pembelajaran yang dilakukan secara online atau jarak jauh. Dalam pembelajaran online tentunya penggunaan teknologi internet dapat dimanfaatkan yakni dengan menjadikan teknologi internet sebagai alat atau media pembelajaran guna membantu kegiatan belajar mengajar tetap terlaksana dengan semestinya.

Dalam penelitian ini dilakukan wawancara dengan beberapa narasumber secara online melalui jaringan telepon untuk mendapatkan sumber data. Adapun wawancara tersebut seputar tentang bagaimana proses pembelajaran matematika dengan penggunaan teknologi internet yang dilakukan di sekolah dasar selama pandemi COVID-19 dan bagaimana dampak penggunaan teknologi internet pada proses pembelajaran matematika sekolah dasar selama masa pandemi

${ }^{23}$ Isrok'atun dkk, Pembelajaran Matematika dan Sains Secara Intergatif Melalui Situation-Based Learning,(Sumedang: UPI Sumedang Press, 2020), hal 14-17. 
covid-19. Tentunya tanggapan guru, orang tua, dan peserta didik terhadap pembelajaran matematika sekolah dasar pada saat pandemi COVID-19 dengan penggunaan teknologi internet berbeda-beda.

Berdasarkan hasil wawancara yang dilakukan, bahwa proses pembelajaran matematika sekolah dasar dilaksanakan secara online atau jarak jauh dan adapula yang dilakukan secara tatap muka dengan hari yang telah ditentukan dari sekolah. Untuk yang dilakukan secara online atau jarak jauh tentunya dengan penggunaan teknologi internet karena agar pelaksanaan kegiatan belajar mengajar terlaksana dengan baik. Sekolah menghimbau para guru untuk menggunakan aplikasi daring yang diharapkan dapat membantu peserta didik dalam proses belajar.

Penggunaan teknologi internet yang digunakan yakni dengan penggunaan whatsapp, zoom meeting, classroom, google form. Mengenal atau melek teknologi harus dilakukan guru, orang tua peserta didik dan peserta didik. Jika dulu belajar hanya melalui tatap muka langsung, sekarang berbagai elemen sudah mengenal whatsapp, google classroom, zoom, dan sebagainya. Mereka harus mulai membudayakan untuk dapat belajar secara online atau jarak jauh. Peran guru tidak lain sebagai menjadi fasilitator dan tutor untuk peserta didik.

Proses pembelajaran, pada awalnya guru memberikan penjelasan secara singkat (materi) kepada peserta didik melalui video yang telah guru buat sebelumnya lalu membagikannya kepada grup kelas di whatsapp. Tidak hanya video, guru terkadang juga memberikan sebuah catatan atau ringkasan yang telah guru rangkum sebelumnya. Hal tersebut dilakukan dikarenakan mengingat yang terkadang materi matematika merupakan sebuah konsep yang abstrak. Lalu kegiatan belajar mengajar dilanjutkan dengan kegiatan tanya jawab melalui google classroom. Selanjutnya guru memberi tugas terkait materi yang telah diajarkan.

Dalam pemberian tugas ini biasanya dilakukan melalui google form atau dalam pemberian tugas di buku siswa lalu guru memberikan batasan waktu untuk mengerjakan tugas yang diberikan. Untuk hasil pekerjaannya difoto dan dikirim melalui grup whatsapp. Adapula yang dalam proses pembelajarannya dengan guru meminta peserta didik untuk mengerjakan tugas yang ada di buku siswa lalu dikumpulkan melalui grup whatsapp yang telah dibuat.

Pembelajaran matematika yang dilakukan secara tatap muka pada hari tertentu yang telah ditentukan dari sekolah, sistemnya dimulai pada jam 07.00 WIB sampai sekitar jam 10.00 WIB, tentunya dengan penerapan protokol kesehatan harus ditetapkan seperti, wajib memakai masker, mencuci tangan dengan sabun yang sudah disediakan dari pihak sekolah didepan kelas, menjaga jarak, dan lain sebagainya guna mencegah penularan COVID-19. Hal tersebut harus dipatuhi oleh guru maupun peserta didik.

Berdasarkan hasil wawancara, terdapat beberapa dampak negatif dan positif dalam pelaksanaan pembelajaran matematika secara online dengan penggunaan teknologi internet dirasakan baik dari guru, orang tua peserta didik dan peserta didik sendiri. Dampak negatif yang 
dirasakan guru adalah ketika pembelajaran dilakukan secara online atau jarak jauh, tidak semua orang tua peserta didik mempunyai fasilitas pendukung proses pembelajaran yakni handphone dan terdapat peserta didik yang lingkungan tempat tinggalnya susah akan sinyal sehingga menjadi proses pembelajaran tidak berjalan secara maksimal.

Dampak negatif yang dirasakan orangtua peserta didik adalah masih terdapat orangtua peserta didik yang gagap akan teknologi internet seperti dalam penggunaan zoom meeting, google classroom dan sebagainya. Perlunya orang tua membeli kuota internet tiap bulan agar dapat mengikuti proses pembelajaran dan perlunya orangtua meluangkan banyak waktu untuk mendampingi anak saat proses pembelajaran online. Dampak yang dialami peserta didik adalah ketidak pahaman peserta didim terhadap teknologi internet dan kurang pahamnya peserta didik dalam memahami pelajaran matematika yang konsepnya abstrak apabila tidak dijelakan menggunakan media. Jadi disini peran orang tua sangat penting untuk mendampingi anaknya dalam proses belajar.

Dampak positif dari penggunaan teknologi internet dalam proses pembelajaran matematika dengan adanya pandemi COVID-19 adalah jika proses pembelajaran dilakukan lewat tatap muka, kini beragam elemen yang sudah familiar seperti whatsapp, Google Classroom, zoom dan lainnya dapat digunakan untuk proses pembelajaran. Sehingga guru, orang tua dan peserta didik dapat melek terhadap teknologi internet. Dampak positif lainnya adalah guru dan peserta didik dapat melakukan proses pembelajaran tersebut kapanpun, dimanapun, tidak tetap proses pembelajaran dilakukan di sebuah ruangan.

Dari hasil penelitian diatas, dikuatkan dari penelitian terdahulu dari Jurnal Pendidikan dan Hasil Penelitian dengan penulis Wiryanto, Universitas Negeri Surabaya, dengan judul penelitiannya "Proses Pembelajaran di SD di Tengah Pandemi Covid-19". Menjelaskan bahwasannya penggunaan teknologi internet dalam proses pembelajaran matematika sekolah dasar di masa pandemi COVID-19 menjadikan semua elemen (guru, orangtua, peserta didik) merasakan terbantu dalam melaksanakan pembelajaran. Sehingga kegiatan pembelajaran tetap terlaksana. ${ }^{24}$

\section{KESIMPULAN DAN SARAN}

Pembelajaran matematika di SD dilakukan secara online atau jarak jauh dengan memanfaatkan penggunaan teknologi internet melalui aplikasi whatsapp, zoom, google classroom. Pembelajaran matematika melalui aplikasi-aplikasi tersebut untuk menerangkan suatu konsep abstrak berupa penjelasan dari guru, pemberian video pembelajaran, serta catatan atau rangkuman yang guru buat supaya peserta didik dapat jelas menerima materi pelajaran. Suatu konsep pada

${ }^{24}$ Wiryanto, Proses Pembelajaran Matematika di Sekolah Dasar di Tengah Pandemi Covid-19, Jurnal Kajian Pendidikan dan Hasil Penelitian, Vol. 6, No. 2, Mei 2019. 
peserta didik sekolah dasar harus diterangkan melalui berbagai media, karena peserta didik sekolah dasar masih masuk pada masa operasional konkrit.

Dampak positifnya dengan adanya pembelajaran online selama COVID-19 adalah semua elemen (guru, orang tua dan peserta didik) dapat melek teknologi dengan mengenal berbagai aplikasi tatap muka yang digunakan untuk mempermudah proses belajar mengajar dengan daring. Selain itu, belajar menjadi lebih fleksibel karena dapat dilakukan dimana saja dan kapan saja serta tidak terpaku oleh ruangan kelas.

Dampak negatif penggunaan teknologi internet dalam proses pembelajaran matematika yang dilakukan secara online selama COVID-19 adalah ketika pembelajaran dilakukan secara online atau jarak jauh, tidak semua orangtua peserta didik mempunyai fasilitas pendukung proses pembelajaran yakni handphone dan terdapat peserta didik yang lingkungan tempat tinggalnya susah akan sinyal sehingga menjadi proses pembelajaran tidak berjalan secara maksimal.

Melonjaknya kebutuhan kuota internet guna untuk mengikuti proses belajar anak, orang tua disibukkan dengan pekerjaan anak dan banyak meluangkan waktu untuk mendampingi anak saat belajar, dan rasa jenuh pada peserta didik yang merasa hanya berkutat pada tugas, serta tidak jelasnya penjelasan guru ketika pembelajaran melalui aplikasi tatap muka ketika signal buruk sehingga materi yang disampaikan menjadi tidak jelas. Hal tersebut terjadi dikarenakan kurang siapnya semua elemen baik itu guru, orangtua dan peserta didik terhadap adanya pembelajaran online atau jarak jauh serta kurangnya sarana dan prasarana yang dapat digunakan untuk pembelajaran saat pembelajaran online ditengah pandemi COVID-19 ini.

Saran agar pembelajaran matematika ditengah masa pandemi COVID-19 dapat berjalan dengan baik, sebaiknya semua elemen (guru, orangtua peserta didik, dan peserta didik) siap dengan penggunaan teknologi internet dalam proses pembelajarn berlangsung. Untuk guru sebaiknya mempersiapkan materi semenarik mungkin agar peserta didik tidak merasa bosan dengan sistem hanya pemberian tugas. Orang tua juga harus turut berpartisipasi aktif untuk mendampingi anaknya belajar. Dan peserta didik harus memanfaatkan waktu luang untuk mendalami materi yang telah diberikan guru.

\section{DAFTAR PUSTAKA}

Rahmania, Annisa dkk. Internet Sehat. Depok : Penebar Plus.

Shirky, Clay. (1995). Internet Lewat E-Mail. Jakarta : PT Elex Media Komputindo.

Depdiknas. (2003). Pembelajaran Matematika. Jakarta : Depdiknas.

Dimyati, dan Mujiono. (2002). Belajar dan Pembelajaran. Jakarta : Rineka Cipta.

Anggawirya, Erhans. Internet. Cirebon : PT Ercontara Rajawali.

Iskandar. (2009). Panduan Lengkap Internet. Yogyakarta : Penerbit ANDI. 
Enterprise, Jubilee. (2010). Panduan Memilih Koneksi Internet untuk Pemula. Jakarta : PT Elex Media Komputindo.

Sidharta, Lani. (1996). Internet : Informasi Bebas Hambatan 2. Jakarta : PT Elex Media Komputindo.

Nolden, Mathias. (1996). World Wide Web di Internet. Jakarta : PT Elex Media Komputindo.

Gatoto, Muksetyo dkk. (2007). Pembelajaran Matematika SD. Jakarta : Universitas terbuka.

Suwangsih dan Tiurlina. (2006). Pembelajaran Matematikan. Bandung : UPI press.

Wiryanto. (2019). Jurnal Kajian Pendidikan dan Hasil Penelitian. Proses Pembelajaran di SD di Tengah Pandemi Covid-19. Universitas Negeri Surabaya., 6(2).

A. Rozi, Zaenal. (2008). Computer Started Guide Mari Mengenal Internet. Yogyakarta : Penerbit ANDI.

Rahmad, Dede dkk. (2020). Jurnal Presepektif Ilmu Pendidikan. Kemandirian Belajar Peserta Didik dalam Pembelajaran Daring Pada Masa Pandemi Covid-19. 34(2).

Hamzah. (2007). Model Pembelajaran. Jakarta : PT. Bumi Aksara.

Isrok'atun dkk. (2020). Pembelajaran Matematika dan Sains Secara Intergatif Melalui SituationBased Learning. Sumedang : UPI Sumedang Press.

Handayani, Oktafia Ika. (2020). Pembelajaran Daring Sebagai Upaya Study From Home (SFH) Selama Pandemi Covid-19. Jurnal Pendidikan Administrasi Perkantoran (JPAP), 8(3).

Prihandoko. (2006). Pemahaman dan Penyajian Konsep Matematika Secara Benar dan Menarik. Jakarta : Dediknas.

Yuhelizar. (2008). 10 Jam Menguasai Internet Teknologi dan Aplikasinya. Jakarta : PT Elex Media Komputindo. 